\title{
Genetic improvement of Bacillus thuringiensis against the cotton bollworm, Earias vitella (Fab.) (Lepidoptera: Noctuidae), to improve the cotton yield in Pakistan
}

\author{
Fakhar-un-Nisa Yunus ${ }^{1 *}$, Ghulam Raza ${ }^{2}$, Rahat Makhdoom ${ }^{3}$ and Hafsa Zaheer ${ }^{1}$
}

\begin{abstract}
In the present study, CrylAc (Crystal protein) gene was cloned under Cry3A promoter, which is known to express vegetatively as a sporulation independent promoter, transformed into acrystalliferous strain of Bacillus thuringiensis. Its potential was evaluated as a strain to be used for formulation development against the spotted cotton bollworm Earias vitella (Fab.) (Lepidoptera: Noctuidae), the major pest of cotton, the important cash crop in Pakistan. The crystal protein produced in a new strain, i.e., Bt1, had comparable potency as of crystal protein produced during sporulation. The new strain Bt 1 had the maximum expression of Cry $1 A c$ protein during the vegetative stage, i.e., in the first $24 \mathrm{~h}$, thereby reducing the growth period until crystal protein production, from 72 to $24 \mathrm{~h}$. In addition, crystal protein produced during vegetative stage under Cry3A promoter remained encapsulated within the cells, which could protect them from UV degradation and was independent of sporulation; therefore; it did not produce spores and thus is not a source to spread Bt spores in the environment. It can, therefore, be called as an environmentally friendly pesticide to control cotton pest especially bollworms and ultimately improve the yield of cotton.
\end{abstract}

Keywords: Genetic improvement, Bacillus thuringiensis, Cry3A promoter, Earias vitella, Biotoxicity assay, Viability assay

\section{Background}

Insect pests cause great damage to different cash crops in farming production. Worldwide yield losses vary widely between crops and different geographic areas. Different schemes have been applied to control this agricultural damage, the principal strategy to cut the impairment being the role of chemical insecticides (Federici et al. 2003). The most widely used microbial pesticide worldwide are those based on preparations of the bacterium Bacillus thuringiensis (Bt). The $B t$ is an aerobic, spore-forming soil bacterium that produces highly specific insecticidal proteins termed as delta endotoxins or Cry (crystal) toxin. Delta endotoxins accumulate as

\footnotetext{
* Correspondence: fakhar_yunus@yahoo.com

${ }^{1}$ Department of Zoology, Lahore College for Women University, 54000- Jail Road, Lahore, Pakistan

Full list of author information is available at the end of the article
}

crystalline inclusions within the cell during sporulation (Reza et al. 2014). Commercial Bt products generally consist of a mixture of spores and crystals, grown in large fermenters and applied as foliar sprays, much like synthetic insecticides. In Pakistan, cotton is susceptible to attack by more than 67 insects, the major lepidopterans bollworms, and they cause heavy damages to cotton yield (FAO 2001).

Biopesticides containing $B t$ are environmentally friendly and effective in a variety of situations. Its products are not as potent or persistent in the field as chemical products. Bt products act slowly have a narrow activity spectrum and are not stable in the environment after spraying because they are quickly inactivated by exposure to sun or other environment (Yunus et al. 2011b). Therefore, the duration of pest control has been frequently too short, and its use on many crops is not 
cost effective because too many applications are required to wipe out the pests (Benjamin et al. 2014). The environmental stability of the crystals after spraying is also significant as it defines the duration of pest control and the number of needed applications.

For increasing their efficacy and persistence, $B t$ toxins for field use and $\mathrm{Cr} r$ genes have been cloned and expressed in other microorganisms. A number of different toxin genes, which are effective against lepidopteran, dipteran and coleopteran larvae, from different strains of $B t$ have been cloned and expressed in different host system (Tabashnik et al. 2004; Zhu et al. 2006; Yunus et al. 2011b; Benjamin et al. 2014). Binding of $B t$ toxins to specific sites in the epithelial membrane is a central step in toxin specificity. By using different chimeric genes and using toxins combination, development of resistance in target insects is delayed (Yunus et al. 2011a; Lemes et al. 2017 and Farhat-Touzri et al. 2018).

The expression systems of the Cry genes differ and consequently do not compete for rate limiting gene expression vectors. The CryI delta endotoxin genes are transcribed from specific sporulation dependent promoters, whereas the Cry3A gene is transcribed from a sporulation-independent promoter, which resembles vegetative promoters of other $\mathrm{Cr} y$ toxin genes. This builds it possible to bring about this toxin or other CryI toxins at high levels in sporulation-deficient or wild-type backgrounds. Therefore, it may be possible to increase the total quantity of $\mathrm{Cry}$ toxin produced in a $B t$ strain (Zhu et al. 2006). In the present study, a new recombinant strain Bt1, in which the crystal protein Cry1Ac produced under $C r y 3 A$ promoter remains encapsulated that provides protective covering of cell membrane around crystal protein to increase stability of toxin in the UV containing environment was developed.

\section{Materials and methods Construction of Cry $1 \mathrm{Ac}$ recombinant strain under Cry $3 \mathrm{~A}$ promoter}

The wild-type strains of HD-73 subspecies Kurstaki, 4AA1 subspecies tenebrionis, and acrystalliferous strain 4D22 modified form of HD-73 were procured from BGSC (Bacillus Genetic Stock Centre, OH, USA). Total genomic DNA isolated from the HD-73 subspecies Kurstaki by Kronstad method (Kronstad 1983) containing the CryIAc gene (Acc \# M11068) and 4AA1 subspecies tenebrionis strain containing the Cry $3 \mathrm{~A}$ promoter (Acc \# M30503) were used to amplify the Cry1Ac gene and Cry3A promoter for cloning into PCR 2.1 TA-cloning vector. The CryIAc construct pAc was PCR amplified from HD-73 genomic DNA with Ac forward and Ac reverse primers, simultaneously incorporating ApaI sites into the both ends of the fragment for cloning into the TA-cloning vector PCR 2.1. The Cry3A construct p3A was obtained by using the 3A forward and $3 \mathrm{~A}$ reverse primers and incorporating the BamHI and ApaI restriction sites into the fragment for cloning into the PCR 2.1 cloning vector (Fig. 1). For comparative study, fulllength CryIAc gene was amplified, employing the 1Ac forward and 1Ac reverse primers and cloning into the TA-cloning vector PCR 2.1 exploiting the Sph1 and BamH1 sites in its polylinker region (Table 1). Plasmid DNA from various clones was prepared by the Alkaline Lysis method (Birnboim and Doly 1970).

Polymerase chain reactions (PCR) were performed by a modification of the method by (Saiki et al. 1988). A total volume of $50 \mu \mathrm{l}$ contained $50-100 \mathrm{ng}$ of DNA template, $0.1 \mathrm{mM}$ dNTPs, $1 \mathrm{pmol} / \mu \mathrm{l}$ of each primer, and 2 units of Taq DNA polymerase in $1 \times$ PCR buffer, 2.5-3 $\mathrm{mM} \mathrm{MgCl}_{2}$, using a PTC-100 thermocycler $(\mathrm{Mj}$ Research Laboratories) according to the expected length of the PCR products. To amplify $\sim 0.2 \mathrm{~kb}$ DNA fragment from Cry3A and $1.8 \mathrm{~kb}$ DNA fragment and $3.9 \mathrm{~kb}$ full-length gene from the CryIAc genomic DNA. The PCR programs were mentioned respectively as follows. For $0.2 \mathrm{~kb}$ promoter, the reaction was performed as $94{ }^{\circ} \mathrm{C}$ for $1 \mathrm{~min}$ followed by 35 cycles, $94{ }^{\circ} \mathrm{C}$ for $45 \mathrm{~s}$, $50^{\circ} \mathrm{C}$ for $45 \mathrm{~s}, 72^{\circ} \mathrm{C}$ for $1 \mathrm{~min}$, and final extension at $72{ }^{\circ} \mathrm{C}$ for $7 \mathrm{~min}$. For $1.8 \mathrm{~kb}$ CryIAc gene coding region, the reaction was performed at $93^{\circ} \mathrm{C}$ for $5 \mathrm{~min}$, followed by 29 cycles, $94{ }^{\circ} \mathrm{C}$ for $45 \mathrm{~s}, 56^{\circ} \mathrm{C}$ for $2 \mathrm{~min}, 72^{\circ} \mathrm{C}$ for 2 min, and final extension at $72{ }^{\circ} \mathrm{C}$ for $10 \mathrm{~min}$ (Fig. 1). Figure 1c depicts the plasmids map for the theoretical sequence in SnapGene (Version 3.0) for Bt1 in pHB201 and Bt2 in pHPS9.

\section{Biotixicity assay}

Artificial diet containing easily available ingredients was developed to rear the target insect (Rahat 1999). The growth of the insects when reared on artificial diet at $\left(29 \pm 2{ }^{\circ} \mathrm{C}\right.$ and $\left.65 \pm 5 \% \mathrm{RH}\right)$ was normal and the larvae completed their development in 17-20 days. The egg hatchability was $100 \%$ and the survival rate larvae were $20 \%$ (Table 2). CryIAc toxin was extracted from Bt kurstaki HD-73 using the procedure described by Bietlot (1990). The toxin concentration was determined by the method of (Bradely Bradford 1976). Different concentrations of activated toxin protein ranging from 10 to $300 \mu \mathrm{g}$ were mixed per gram of diet and air-dried. Two second instar spotted bollworm larvae were placed in each vial containing $2 \mathrm{~g}$ of diet. Each assay was performed in triplicate. For a negative control, comparable quantity of the buffer and trypsin was added to the diet, air-dried, and assay established in triplicates. Mortality was monitored till $72 \mathrm{~h}$. Bioassay data were statistically analyzed using Quantal Computer Program at Centre of Excellence in Molecular Biology (CEMB) (Fig. 2). 


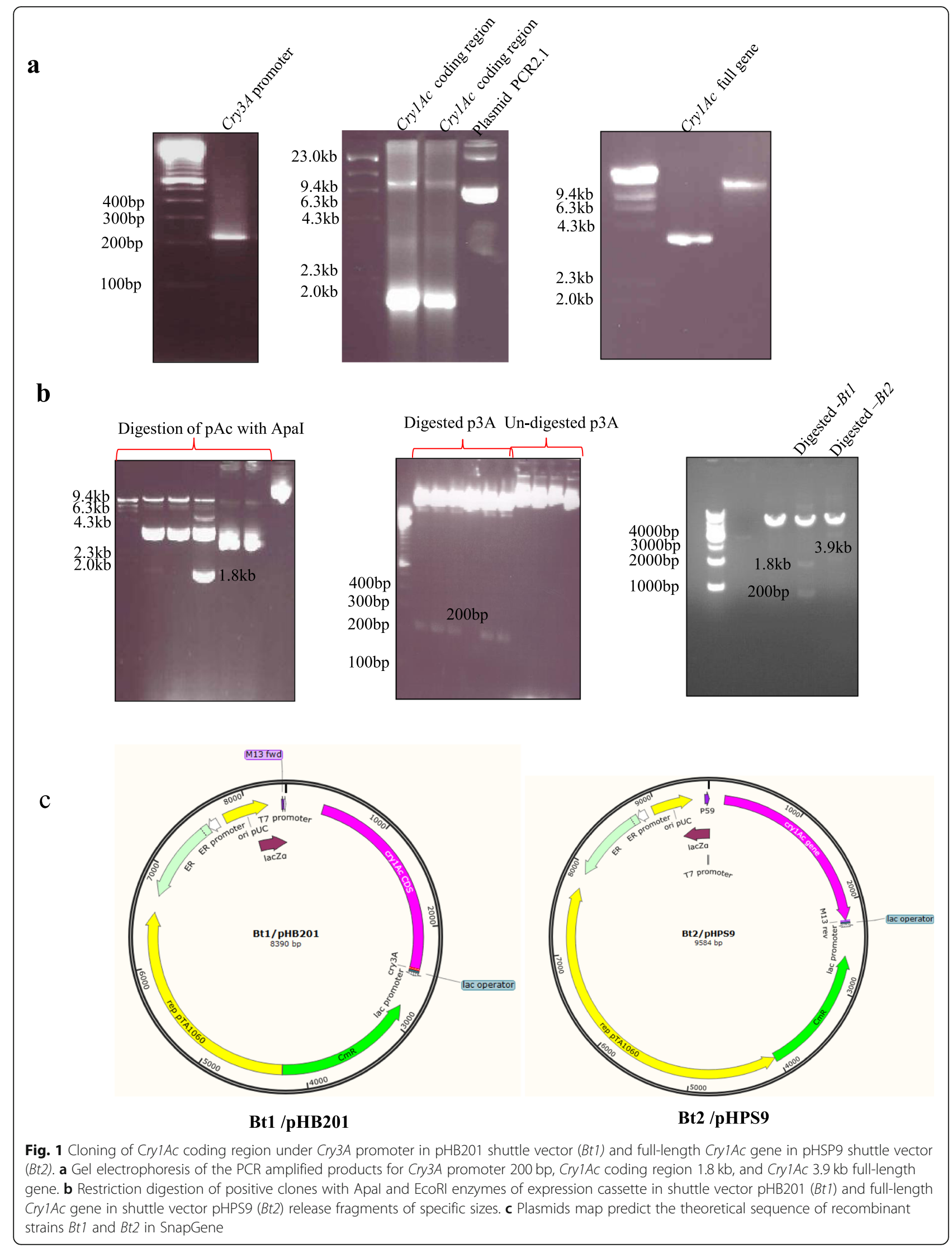


Table 1 Forward and reverse primers of Cry $1 A C$ genes and Cry $3 A$ promoter region

\begin{tabular}{ll}
\hline Gene/Promoter & Primers \\
\hline Primers for full length CrylAc gene & Forward \\
& $5^{\prime}$ ATGCATGCGTGAATTGCAGGTAAATGGTTC 3' Sph1 \\
Reverse & $5^{\prime}$ CGGGATCCTTACTATTCCTCCATAAGGAGTAAT 3' BamH1 \\
Primers for coding region of CrylAc gene & 1Ac Forward \\
Primers for Cry3A promoter region & $5^{\prime}$ TाTGGGCCCATGGATAACAATCCGA 3' Apa1 \\
& 1Ac Reverse \\
& $5^{\prime}$ TाTGGGCCCTTCAGCCTCGAGTG 3' Apa1 \\
& Pro Forward \\
& $5^{\prime}$ CGGGATCCGGACTATTATAATCAT 3' BamH1 \\
\hline
\end{tabular}

\section{Cell viability assay}

For the laboratory biotoxicity assay, dry and wet formulations were developed for recombinant strains of $B t 1$ and Bt2, and spore viability assay was performed for both formulations. Cell viability assay for recombinant $B t$ strain $B t 1$ was performed with acetone. For this purpose, Bt1 was grown in $500 \mathrm{ml} \mathrm{LB-}$ Chloramphenicol $(10 \mu \mathrm{g} / \mathrm{g})$ at $37^{\circ} \mathrm{C}$ for $24 \mathrm{~h}$, followed by harvesting cells at $7000 \mathrm{RPM}$ at $4^{\circ} \mathrm{C}$ for $10 \mathrm{~min}$, and cells were washed twice by resuspending the cell pellet in acetone and centrifugation afterward. One gram of pellet was resuspended in $9 \mathrm{ml}$ of autoclaved $0.89 \%$ saline solution and vortexes thorough. This dilution was used as a stock to prepare six further serial dilutions. From each of first six serial dilutions, $100 \mu \mathrm{l}$ was spread on LB-chloramphenicol plates in triplicates for

Table 2 Life cycle of spotted bollworm (Earias vitella) on locally developed synthetic diet for laboratory bioassay

\begin{tabular}{ll}
\hline Stage of larvae & Days and percentage \\
\hline Egg stage & \\
Egg hatching time & $6-7$ days \\
Egg hatching & $90 \%$ \\
Larval stage & \\
Survival rate of neonatal larvae & $80 \%$ \\
Survival rate of second and four instar larvae & $98 \%$ \\
Time period (neonatal to four instar) & 18 days \\
Pupal stage & \\
Pupation after four instar & $95 \%$ \\
Time period (pupa to moth) & $5-9$ days \\
Adult stage (moth) & \\
Moth emergence rate & $80 \%$ \\
Longevity & $5-8$ days \\
\hline
\end{tabular}

each dilution. Positive control contained cells washed with autoclaved saline instead of acetone. Plates were incubated at $30^{\circ} \mathrm{C}$ overnight. The positive control plates showed growth in all plates whereas treated pellet with acetone showed very few colonies in first three dilutions, and there was no growth in plates for further three dilutions. When bioassays were performed for both types of pellets against the target pest, similar larval mortality was observed in control cells as well as in treating cells (Fig. 2).

\section{Leaf bioassay for Bt 1 formulation}

Infectivity test was conducted to check the fate of $B t 1$ formulation in the laboratory against E. vitella. These treatment contained ten replicates. In the petri plates, to retain moisture on the round filter paper $1 / 2 \mathrm{ml}$, water was spreaded. Top tender undamaged leaves of about $4 \mathrm{~cm}$ in length were plucked from CEMB cotton field. Leaves were washed by sterilized distilled water to remove dust particles. The formulation was weighed as $1.25 \mathrm{~g}$ and mixed in $500 \mathrm{ml}$ sterilized distilled water. Ten leaves were sprayed by a prepared solution using a hand sprayer, then air-dried the leave; for control, simple sterilized distilled water was used. Second instar larvae of E. vitella were kept on leave for $72 \mathrm{~h}$. Mortality was recorded, after $72 \mathrm{~h}$.

\section{Results and discussion}

Resistance development is the major hurdle for $B t$ biopesticide. The present study addresses such problem and developed an improved recombinant strain Bt1 in which crystal protein was protected from UV degradation and avoided the spreading of spores in the environment. For this purpose, the expression of an active toxin fragment of $C r y I A c$ gene was studied under the $C r y 3 A$ promoter. It has been well documented that unlike $\mathrm{Cry} 1 \mathrm{Ac}, \mathrm{Cry} 3 \mathrm{~A}$ 
a

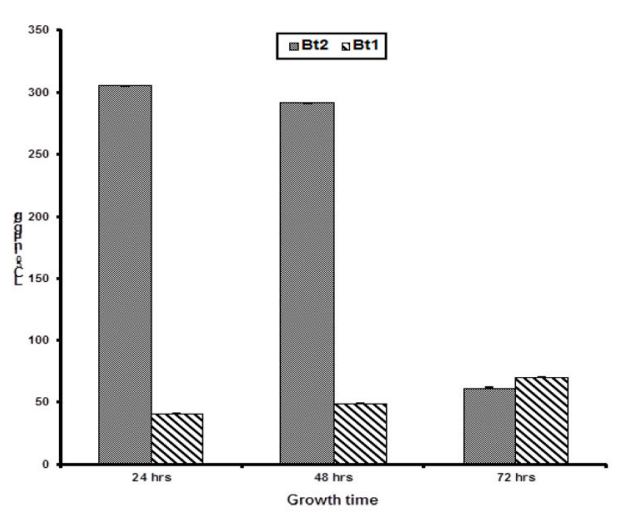

C

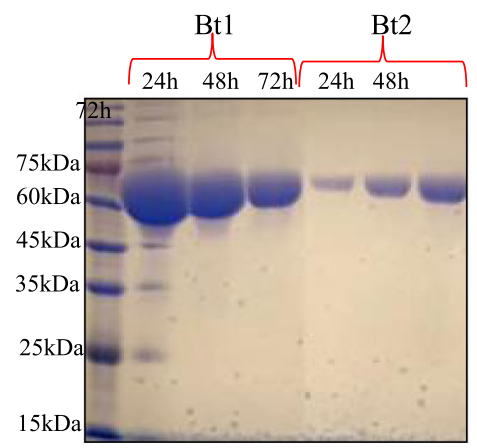

b

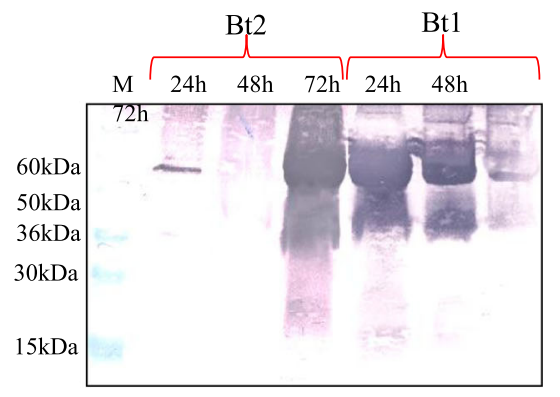

d

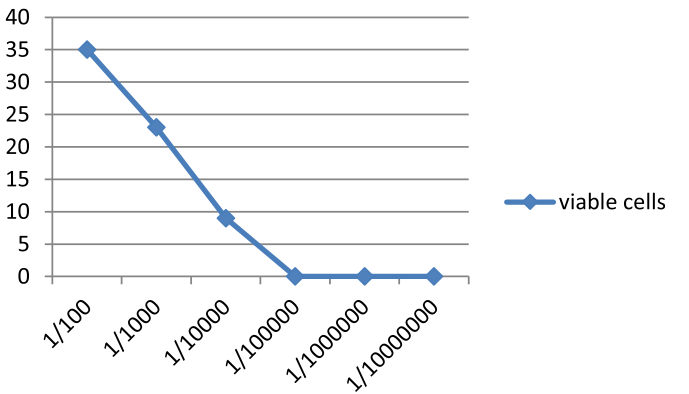

Fig. 2 Graphical representation of biotoxicity assay against Earias vitella, cell viability assay, SDS-polyacrylamide gel electrophoresis, and western blot analysis of the new recombinant strains. a Biotoxicity assay results of two recombinant strains after 24, 48, and $72 \mathrm{~h}$. against Earias vitella spotted bollworm (b, c) showed the expression of Bt1 Cry protein after 24, 48, and $72 \mathrm{~h}$ under Cry $3 \mathrm{~A}$ promoter whereas Bt2 showed expression of Cry 7 Ac after sporulation at $72 \mathrm{~h}(\mathbf{d})$. Viability assay showed the viable cells of Bt 1 wet formulation are different

expression is independent of the genes involved in the initiation of sporulation and sporulation sigma factors $\sigma \mathrm{E}$ and $\sigma \mathrm{K}$. The $C r y 3 A$ gene expression is activated at the onset of stationary phase from a promoter resembling those recognized by the RNA polymerase containing primary sigma factor $\sigma A$ (Agaisse and Lereclus 1995). Therefore, transcription at the $\mathrm{Cry} 3 \mathrm{~A}$ promoter is initiated earlier than the promoters of other Cry genes that are transcribed by RNA polymerase containing sporulation-specific sigma factors, $\sigma \mathrm{E}$ and $\sigma \mathrm{K}$. The gene expression under $\mathrm{Cry} 3 \mathrm{~A}$ promoter can make it possible to produce this toxin at high levels before the onset of sporulation in $B t$.

The CryIAc active toxin fragment from Bt kurstaki HD73 from BGSC (Bacillus Genetic Stock Centre) was cloned under the Cry3A promoter sequences obtained from $B t$ strain tenebrionis 4AA1 (BGSC). Expression studies of Cry $1 A c$ from strains Bt1 revealed that only $24 \mathrm{~h}$ of growth were required to obtain maximum levels of toxin under the vegetative Cry $3 \mathrm{~A}$ promoter in comparison to the $B t 2$ strain, where the expression of $\mathrm{Cry} 1 A c$ gene reached its maximum level after $72 \mathrm{~h}$, from its native, sporulationdependent promoter. The expression of Cry1Ac in Bt2 strain was comparable to the expression of $\mathrm{Cry} 1 \mathrm{Ac}$ in $\mathrm{Bt}$ kurstaki strain HD-73 (Figs. 1 and 2). Several studies have been conducted so far indicating that the $C r y 3 A$ promoter was able to enhance the expression of other Cry genes and significantly increased the production of those Cry proteins (Kronstad et al. 1983;Cannon 1995; Park et al. 1998). Recently, Chen et al. (2005) reported that both Cry3A promoter and promoter/Shine-Dalgarno sequence combinations were able to enhance synthesis of Vip184 and to change its expression time course in the different $B t$ strains. Another survey suggested that the amount of Vip3Aa7 protein produced under the control of Cry3A promoter was two to three folds more than that of vip3Aa7 native promoter. Chaoyin et al. (2007) demonstrated recently that the yields of $C r y 1 A c$ protein obtained from $C r y 3 A$ promoter were higher than that produced from $C r y 1 A c$ promoter. In comparison to the expression of full-length $C r y 1 A c$ protein, the expression of an active toxin fragment of $\mathrm{Cry} 1 \mathrm{Ac}$ from $\mathrm{Cry} 3 \mathrm{~A}$ promoter was found. Interestingly, the absence of $\mathrm{C}$-terminal sequences of $\mathrm{Cry} 1 \mathrm{Ac}$ required for the packaging and crystal formation does not seem to interfere the stability or efficacy of the toxin. Wet and dry sprayable formulations of $B t 1$ and $B t 2$ recombinant strains were successfully developed. The field bioactivity assays against $E$. vitella showed comparable efficacies of both formulations. Comparative 
laboratory assays of $\mathrm{Cry} 1 \mathrm{Ac}$ proteins produced from $\mathrm{Bt1}$ and Bt2, after 24, 48, and $72 \mathrm{~h}$ respectively, for the maximum toxin yield, against $E$. vitella demonstrated slightly lower LC50 values $(40.5 \pm 0.35 \mu \mathrm{g} / \mathrm{g})$ for $B t 1$ than in $B t 2$ $(61 \pm 0.71 \mu \mathrm{g} / \mathrm{g}$ ) suggesting $B t 1$ to be more effective (Fig. 2a). The biotoxicity assays showed that after killing the vegetative cells in formulation, there was no effect on protein activity and percentage of insect mortality, which was the same for both viable and non-viable cells (Fig. 2d).

\section{Conclusion}

The new strain Bt1 had the maximum expression of Cry $1 A c$ protein during the vegetative stage, i.e., in first $24 \mathrm{~h}$ reducing the growth period until the maximum toxin yield, from 72 to $24 \mathrm{~h}$, and thereby significantly reducing the production cost. In addition, the crystal protein produced during vegetative stage under Cry $3 \mathrm{~A}$ promoter remains encapsulated that provides a protective covering of cell membrane around crystal protein to increase stability of toxin in the UV containing environment. Most importantly, this approach provides a mean to produce spore-free, environment friendly formulation as sporulation ensues well after 24 h. Preliminary data showed that the $B t 1$ formulation was as stable as Bt2 with reference to formulation development and storage in dried form; however, more studies are required to estimate their comparative stability against UV under field environment.

\section{Abbreviations}

Bt: Bacillus thurigiensis; Bt1: Recombinant strain of Cry 7 Ac under Cry $3 \mathrm{~A}$ promoter in pHB201; Bt2: Recombinant strain of full-length Cry1Ac gene in pHPS9; Cry: Crystal protein; Cry: Crystal protein gene; PCR: Polymerase chain reaction

\section{Acknowledgements}

The authors appreciate from research Centre of Excellence in Molecular Biology, University of the Punjab, Lahore.

\section{Author's contributions}

FY and RM designed the work. FY did the experiments and analyzed the data. FY, GR, and $H Z$ were involved in the MS preparation and revised the paper. All authors read and approved the final manuscript.

\section{Funding}

The work is part of the first author's PhD dissertation which was supported and facilitated by Centre of Excellence in Molecular Biology, University of the Punjab (CEMB), Lahore, Pakistan.

\section{Availability of data and materials \\ NA}

\section{Ethics approval and consent to participate}

NA

\section{Consent for publication}

This is to state that this work is the author's PhD dissertation work so I give permission for the publication.

\section{Competing interests}

The authors declare that they have no competing interests.

\section{Author details}

'Department of Zoology, Lahore College for Women University, 54000- Jail Road, Lahore, Pakistan. ${ }^{2}$ Mayo Hospital, Main Clinical Laboratory, Lahore, Pakistan. ${ }^{3}$ Agriculture and Agri-Food Canada, Lethbridge Research Centre, Lethbridge, Alberta T1J 4B1, Canada.

Received: 24 June 2019 Accepted: 26 September 2019

Published online: 20 November 2019

\section{References}

Agaisse H, Lereclus D (1995) How does Bacillus thuringiensis produce so much insecticidal crystal protein. J Bacteriol 177:6027-6032

Benjamin R, Deist, Michael A, and Rausch, Maria TA, Fernandez-Luna, Michael JA, Bryony C. B (2014) Bt toxin modification for enhanced efficacy. Toxin (Basel) 6(10): 3005-3027.

Bietlot H (1990) Characterization of the cysteine residues and disulphide linkages in the protein crystal of Bacillus thuringiensis. J Biochem 267:309-315

Birnboim HC, Doly JA (1970) A rapid alkaline extraction procedure for screening recombinant plasmid DNA. Nucl Acid Res 7:1513-1523

Bradley Bradford MM (1976) A rapid sensitive method for the quantitation of microgram quantities of protein utilizing the principle of protein-dye binding. Anal Biochem 72:248-254

Cannon RJC (1995) Bacillus thuringiensis in pest control. In: Biological control: benefits and risks [H.M.T. Hokkaneu and T.H. Lynch, (ed)]. Cambridge University Press, Cambridge, England, p 190-200.

Chaoyin Y, Wei S, Sun F, Lin Faju C, Zhengquan H, Ziniu Y (2007) Comparative study on effect of different promoters on expression of Cry $7 A c$ in Bacillus thuringiensis chromosome. J App Microbiol 103:454-461

Chen J, Sun F, Shi Xu W, Guo W, Pang Y (2005) Efficient expression of vip $184 \Delta$ P gene under the control of promoters plus Shine-Dalgarno (SD) sequences of Cry genes from Bacillus thuringiensis. J App Microbiol 99:426-434

F.A.O (2001) Food and Agriculture Organization of the United Nations, Viale delle Terme di Caracalla, 00100 Rome, Italy. Online detabase of Provisional Production and production Indices data. URL. http://www.fao.com.

Farhat-Touzri DB, Jemli S, Driss F, Tounsi S (2018) Molecular and structural characterization of a novel Cry1D toxin from Bacillus thuringiensis with high toxicity to Spodoptera littoralis (Lepidoptera: Noctuidae). Inter J Biol Macro 8130(18):33583-33589

Federici BA, Park HW, Bideshi DK, Wirth MC, Johnson JJ (2003) Recombinant bacteria for mosquito control. J Exp Biol 206:3877-3885

Kronstad JW, Schnepf HE, Whiteley HR (1983) Diversity of location for Bacillus thuringiensis crystal protein genes. J Bacteriol 154:414-428

Lemes ARN, Camila SF, Isis S, Liliane MS, Rebeka DCA, Herbert Á, Herbert AAS, Manoel VF, OAF L, Janete AD (2017) Cry1Ac and Vip3Aa proteins from Bacillus thuringiensis targeting Cry toxin resistance in Diatraea flavipennella and Elasmopalpus lignosellus from sugarcane. Peer I 5:e2866

Park HW, Ge B, Burner LS, Federici BA (1998) Optimization of Cny3A yields in Bacillus thuringiensis by use of sporulation dependent promoters in combination with the STAB-SD mRNA sequence. J Appl Envir Microbiol 64:3932-3938

Rahat M (1999) Cloning and sequencing of the delta endotoxin gene from locally isolated Bacillus thuringiensis. University of the Punjab, Dissertation

Reza TH, Raziyeh B, Vahid H, Ayda K (2014) Effect of midgut proteolytic activity on susceptibility of lepidopteran larvae to Bacillus thuringiensis subsp. kurstaki. Front Physiol / Invert Physiol 4: 406.

Saiki RK, Gelfand DH, Stoffel S, Scharf SJ, Higuchi R, Horn GT, Mullis KB, Erlich HA (1988) Primer-directed enzymatic amplification of DNA with a thermostable DNA polymerase. Scie 239:487-491

Tabashnik BE, Liu YB, Unnithan DC, Carriere Y, Dennehy TJ, Morin S (2004) Delaying evolution of insect resistance to transgenic crops by decreasing dominance and heritability. J. Evol. Biol. 17(4):904-912

Yunus F, Malik K, Raza G, Makhdoom R (2011a) Additive effect of neem (Azadirachta indica) with Bacillus thuringiensis Cry protein. Inter. J cell Mol Biol 2(2):576-579

Yunus F, Raza G, Makhdoom R (2011 b) Synergism between Bacillus thuringiensis toxins CrylAC and Cry2A against Earias vitella. Pak J Zool 43(3):575-580

Zhu C, Ruan L, Peng D, Yu Z, Sun M (2006) Vegetative insecticidal protein enhancing the toxicity of Bacillus thuringiensis subsp. kurstaki against Spodoptera exigua. Lett Appl Microbiol 42(2):109-114

\section{Publisher's Note}

Springer Nature remains neutral with regard to jurisdictional claims in published maps and institutional affiliations. 